\title{
Kribellosides, novel RNA 5'-triphosphatase inhibitors from the rare actinomycete Kribbella sp. MI481-42F6
}

\author{
Masayuki Igarashi ${ }^{1}$, Ryuichi Sawa ${ }^{1}$, Manabu Yamasaki ${ }^{1}$, Chigusa Hayashi ${ }^{1}$, Maya Umekita ${ }^{1}$, Masaki Hatano ${ }^{1}$, \\ Toshinobu Fujiwara ${ }^{1,3}$, Kiyohisa Mizumoto ${ }^{2}$ and Akio Nomoto ${ }^{1}$ \\ Yeast capping enzymes differ greatly from those of mammalian, both structurally and mechanistically. Yeast-type capping \\ enzyme repressors are therefore candidate antifungal drugs. The 5'-guanine-N7 cap structure of mRNAs are an essential feature \\ of all eukaryotic organisms examined to date and is the first co-transcriptional modification of cellular pre-messenger RNA. \\ Inhibitors of the RNA 5'-triphosphatase in yeast are likely to show fungicidal effects against pathogenic yeast such as \\ Candida. We discovered a new RNA 5'-triphosphatase inhibitor, designated as the kribellosides, by screening metabolites \\ from actinomycetes. Kribellosides belong to the alkyl glyceryl ethers. These novel compounds inhibit the activity of Cet1p \\ (RNA 5'-triphosphatase) from Saccharomyces cerevisiae in vitro with $\mathrm{IC}_{50} \mathrm{~S}$ of 5-8 $\mu \mathrm{m}$ and show antifungal activity with MICs \\ ranging from 3.12 to $100 \mu \mathrm{g} \mathrm{ml}^{-1}$ against $S$. cerevisiae.
}

The Journal of Antibiotics (2017) 70, 582-589; doi:10.1038/ja.2016.161; published online 11 January 2017

\section{INTRODUCTION}

Candidiasis is a fungal infection caused by yeasts of the genus Candida. Candida is the fourth most common cause of healthcare-associated bloodstream infections. These infections predominantly affect immunocompromised patients, including those with AIDS or cancer, or those who have received organ transplants. Currently, there are only a few systemic antifungal drugs (amphotericin B, flucytosine, several azole drugs and echinocandins) that are available for the treatment of such invasive candidiasis, and not all of these are satisfactory in terms of efficacy, toxicity, their antifungal spectra, or the possibility of drug resistance. There is thus an urgent need for the discovery and development of novel anti-Candida drugs, especially those which have a different mode of action from the currently available drugs.

The $5^{\prime}$ guanine-N7 cap has been found to be an essential feature of all eukaryotic organisms examined to date and is the first co-transcriptional modification of cellular pre-messenger RNA. ${ }^{1-3}$ The first step of cap formation is the removal of $\gamma$-phosphate from the RNA 5'-triphosphate end of newly synthesized RNA to generate a diphosphate end by RNA 5'-triphosphatase. Then the GMP moiety of GTP is transferred to the $5^{\prime}$-diphosphate terminus by mRNA guanylyltransferase. After these two consecutive reactions, methylation at the guanine-N7 position catalyzed by mRNA (guanine-N7-) methyltransferase follows. Saccharomyces cerevisiae RNA 5'-triphosphatease (Cetlp) is a member of the divalent cation-dependent triphosphatase family observed in protozoa, eukaryotic viruses and fungi. ${ }^{4-7}$ The X-ray structure of Cetlp revealed the location of two independent active sites within parallel tunnels that are formed by homodimerization of a domain..$^{5}$ In yeast such as S. cerevisiae and Candida albicans, the triphosphatase and guanylyltransferase are encoded by distinct genes whose protein products form a noncovalent complex. By contrast, in mammals and plants, the triphosphatase and guanylyltransferase occur in a single-polypeptide chain. Although the guanylyltransferase domain is conserved across evolution, the triphosphatase domain is a metal-independent enzyme that shares structural homology with the cysteine phosphatase superfamily. ${ }^{8-10}$

Thus, the capping enzymes of yeast differ greatly from the capping enzymes of mammals, both structurally and mechanistically, and inhibitors directed against Cetlp may have a fungicidal effect and may be active against clinically important pathogenic yeasts.

During the course of our screening program for new Cetlp inhibitors from metabolites of actinomycetes using a Cetlp enzyme assay system, we found that a strain of Kribbella sp. MI481-42F6 produced new antibiotics, namely kribellosides (Figure 1a,b). Kribellosides showed moderate RNA 5'-triphosphatase inhibitory activities with moderate anti-yeast activities against $S$. cerevisiae. In this paper, we describe the isolation, structural determination and biological activity of new RNA 5'-triphosphatase inhibitors, kribellosides.

\section{RESULTS AND DISCUSSION}

Taxonomy of the antibiotic-producing strain

Strain MI481-42F6 was isolated from a soil sample collected at Nerima-ku, Tokyo, Japan. This strain formed well-branched substrate

${ }^{1}$ Institute of Microbial Chemistry (BIKAKEN), Tokyo, Japan and ${ }^{2}$ Department of Biochemistry, School of Pharmacy, Kitasato University, Tokyo, Japan

${ }^{3}$ Current address: Department of Biochemistry, Faculty of Pharmacy, Kindai University, Osaka, Japan.

Correspondence: Dr M Igarashi, Institute of Microbial Chemistry (BIKAKEN), Laboratory of Microbiology, 3-14-23 Kamiosaki, Shinagawa-ku, Tokyo 141-0021, Japan.

E-mail: igarashim@bikaken.or.jp

This paper is dedicated to Professor Dr Satoshi Ōmura for his Nobel Prize in Physiology or Medicine 2015.

Received 14 October 2016; revised 16 November 2016; accepted 24 November 2016; published online 11 January 2017 
a<smiles>CC(C)CCCCCCCCCCCCOCC(O)CO[C@H]1O[C@H](C(=O)O)[C@H](O[C@@H]2O[C@H](CO)[C@@H](O)[C@H](O)[C@H]2O)[C@H](O)[C@H]1O</smiles><smiles>CC(C)CCCCCCCCCCCCOCC(O)CO[C@H]1O[C@H](C(=O)O)[C@H](O)[C@H](O)[C@H]1O</smiles>
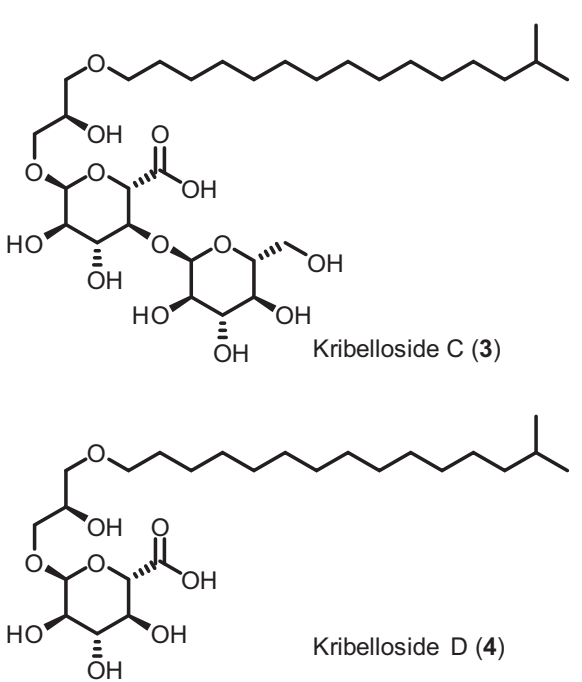

b

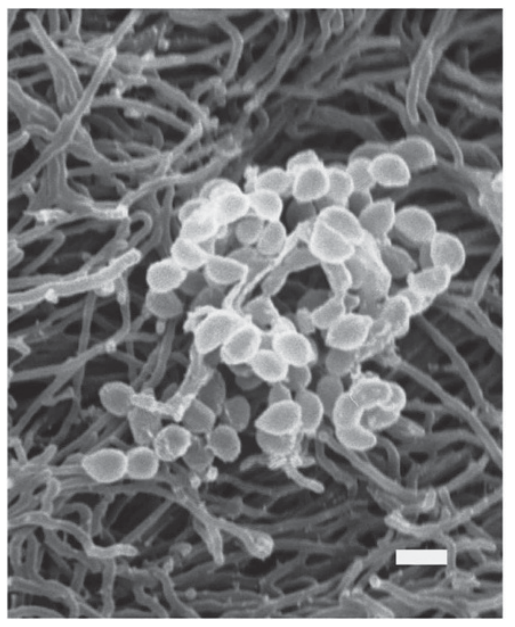

Figure 1 (a) Structure of kribellosides A, B, C and D. (b) Electron micrograph of the kribelloside producer Kribbella sp. MI481-42F6. Kribbella sp. MI481-42F6 was grown on oatmeal agar (ISP medium No. 3) for 14 days at $30^{\circ} \mathrm{C}$. Bar, $1 \mu \mathrm{m}$.

mycelia and straight to flexuous aerial mycelia. Mature spore chains consisted of 8 to 10 or more spores. Each spore was oval in shape with a smooth surface and was $0.6 \times 0.8-0.9 \times 1.1 \mu \mathrm{m}$ in size. The substrate mycelia were pale yellow to pale yellowish brown, whereas aerial mycelia were white. Diaminopimelic acid isomers were of the LL-type. The partial $16 \mathrm{~S}$ ribosomal RNA gene sequence (1450 bp) was determined and submitted to the GenBank/EMBL/DDBJ database under accession number LC049957. The gene sequence showed high similarity with those of the genus Kribbella, such as Kribbella aluminosa (JCM 14599 ${ }^{\mathrm{T}}, 1419 / 1432 \mathrm{bp}$, T: Type strain, 99.1\%) ${ }^{11}$ and K. solani (JCM 12205 ${ }^{\mathrm{T}}, 1433 / 1453$ bp, $\left.98.6 \%\right) .{ }^{12}$

These phenotypic and genotypic data suggested that strain MI481-42F6 belongs to the genus Kribbella. Therefore, the strain was tentatively designated as Kribbella sp. MI481-42F6. Detailed taxonomic studies of strain MI481-42F6 are now underway.

\section{Fermentation and isolation of kribellosides}

Yeast Cetlp requires magnesium ions for RNA 5'-triphosphatase activity, but has been reported to exert the nucleoside triphosphatase activity in the presence of manganese ions. ${ }^{13}$ Therefore, we monitored kribellosides using an in vitro enzyme assay to determine their inhibitory effect on Cetlp nucleoside triphosphatase activity during the purification process. The fermentation of kribellosides was performed by culturing in a 500-ml baffled Erlenmeyer flask containing $110 \mathrm{ml}$ of a producing medium with rotary shaking. The fermentation broth (4l) was separated into the mycelial cake and the supernatant by centrifugation. The mycelial cake was extracted with $\mathrm{MeOH}$ (11). The extract, including an active substance, was sequentially extracted with $\mathrm{BuOH}$ and a mixture of $\mathrm{CHCl}_{3}-\mathrm{MeOH}-$ water (5:4:6) yielding a brown material $(764 \mathrm{mg})$. The brown material was subjected to chromatography on a low-pressure reversed-phase $\left(\mathrm{C}_{18}\right)$ column and was developed with $\mathrm{MeOH}$ :ammonium carbonate $(5 \mathrm{~mm})$ at a ratio of $0: 100,60: 40,80: 20$ and 100:0. The active fractions were collected and further chromatography was performed by reversed-phase HPLC and developed with acetonitrile/ammonium carbonate $(5 \mathrm{~mm})$. The active fractions were collected and concentrated in vacuo to yield $79 \mathrm{mg}$ of pure kribelloside $\mathrm{A}(\mathbf{1}), 83 \mathrm{mg}$ of kribelloside $\mathrm{B}(2), 26 \mathrm{mg}$ of kribelloside $\mathrm{C}(3)$ and $13 \mathrm{mg}$ of kribelloside $\mathrm{D}(4)$, respectively, as a colorless powder.
Physico-chemical properties and structure determination of the kribellosides

The physico-chemical properties of compounds 1, 2, 3 and 4 are shown in Supplementary Table S1. The optical rotations of compounds $1-4$ were $+103.8^{\circ},+61.7^{\circ},+95.7^{\circ}$ and $+50.4^{\circ}$, respectively (c $0.5, \mathrm{MeOH})$. Their UV spectra showed no characteristic absorption. The molecular formulas of compounds 1-4 were determined to be $\mathrm{C}_{30} \mathrm{H}_{56} \mathrm{O}_{14}, \mathrm{C}_{24} \mathrm{H}_{46} \mathrm{O}_{9}, \mathrm{C}_{31} \mathrm{H}_{58} \mathrm{O}_{14}$ and $\mathrm{C}_{25} \mathrm{H}_{48} \mathrm{O}_{9}$, respectively, by high-resolution electrospray ionization mass spectrometry (HRESIMS, negative-ion mode), revealing a difference of $\mathrm{CH}_{2}$ between 1,2 and 3, 4 and $\mathrm{C}_{6} \mathrm{H}_{10} \mathrm{O}_{5}$ between $\mathbf{1}, \quad 3$ and 2, 4. The LC-HRESI-MS indicated that $\mathbf{1}$ and $\mathbf{2}$ share the same in source fragment of $m / z 303.2896\left(\mathrm{C}_{18} \mathrm{H}_{39} \mathrm{O}_{3}\right)$ and 3 and 4 possessed the fragment of $m / z 317.3052\left(\mathrm{C}_{19} \mathrm{H}_{41} \mathrm{O}_{3}\right)$, as shown in Figure $2 \mathrm{a}$.

The NMR data for the kribellosides are summarized in Table 1. Compound 1 had 1 carbonyl, 2 anomers, 9 oxymethines, $1 \mathrm{sp}^{3}$ methine, $4 \mathrm{r}$ oxygenated methylenes, 11 methylenes and 2 methyl carbons, as determined by ${ }^{13} \mathrm{C}$ NMR and DEPT135 spectra. The ${ }^{1} \mathrm{H}^{1} \mathrm{H}$ COSY and TOCSY spectra of compound 1 established the five parts shown in Figure 2b. Correlations were observed from the oxymethine of $\delta_{\mathrm{H}} 3.96(\mathrm{H} 2)$ to the oxymethylene at $\delta_{\mathrm{H}} 3.40,3.83(\mathrm{H} 1)$ and oxymethylene at $\delta_{\mathrm{H}} 3.46,3.49(\mathrm{H} 3)$, suggesting a glyceryl moiety. The cross peaks observed from the anomer proton at $\delta_{\mathrm{H}} 4.82\left(\mathrm{H}^{\prime}\right)$ to oxymethine at $\delta_{\mathrm{H}} 4.07\left(\mathrm{H} 5{ }^{\prime}\right)$ within three oxymethines $\left(\delta_{\mathrm{H}} 3.51\left(\mathrm{H} 2^{\prime}\right)\right.$, $\delta_{\mathrm{H}} 3.91\left(\mathrm{H}^{\prime}\right)$ and $\left.\delta_{\mathrm{H}} 3.71\left(\mathrm{H}^{\prime}\right)\right)$, and from another anomer proton at $\delta_{\mathrm{H}} 5.27\left(\mathrm{H}^{\prime \prime}\right)$ to the oxymethylene at $\delta_{\mathrm{H}} 3.65$ and $3.81\left(\mathrm{H}^{\prime \prime}\right)$ within four oxmethines $\left(\delta_{\mathrm{H}} 3.37\left(\mathrm{H} 2^{\prime \prime}\right), \delta_{\mathrm{H}} 3.62\left(\mathrm{H} 3^{\prime \prime}\right), \delta_{\mathrm{H}} 3.26\left(\mathrm{H} 4^{\prime \prime}\right)\right.$ and $\delta_{\mathrm{H}}$ $\left.3.72\left(\mathrm{H}^{\prime \prime}\right)\right)$ suggested two sugar moieties. The remaining portion might be a branched long alkyl chain from the oxymethylene at $\delta_{\mathrm{H}} 3.46(\mathrm{H} 4)$ to the terminal branched dimethyl protons at $\delta_{\mathrm{H}} 0.88$ $(\mathrm{H} 17,18)$ revealed by the 13 -methyl-1-tetradecanol moiety. The connectivities of these parts were established by HMBC spectroscopy, the long-range couplings; $\mathrm{H}^{\prime} / \mathrm{Cl}^{\prime}$ (anomer at $\delta_{\mathrm{C}} 100.9$ ) and carboxyl carbon at $\delta_{\mathrm{C}} 175.2\left(\mathrm{C}^{\prime}\right)$ and large proton-proton couplings from $\mathrm{H}_{2}{ }^{\prime}$ to $\mathrm{H}^{\prime}(9.4-9.5 \mathrm{~Hz})$ and ROEs between $\mathrm{H}^{\prime}$ and $\mathrm{H}^{\prime} 5^{\prime}$ revealed an $\alpha$-glucuronic acid moiety. Long-range couplings, $\mathrm{H}^{\prime \prime} / \mathrm{C} 1$ " (anomer at $\left.\delta_{\mathrm{C}} 101.2\right)$ and large couplings from $\mathrm{H} 2^{\prime \prime}$ to $\mathrm{H}^{\prime \prime}(9.5 \mathrm{~Hz})$ and ROEs between $\mathrm{H}^{\prime \prime}$ and $\mathrm{H}^{\prime \prime}$ revealed an $\alpha$-glucose moiety. The HMBC correlation of $\mathrm{H1}^{\prime \prime} / \mathrm{C} 4$ ' established an $\alpha-1,4$ bond between glucose and 


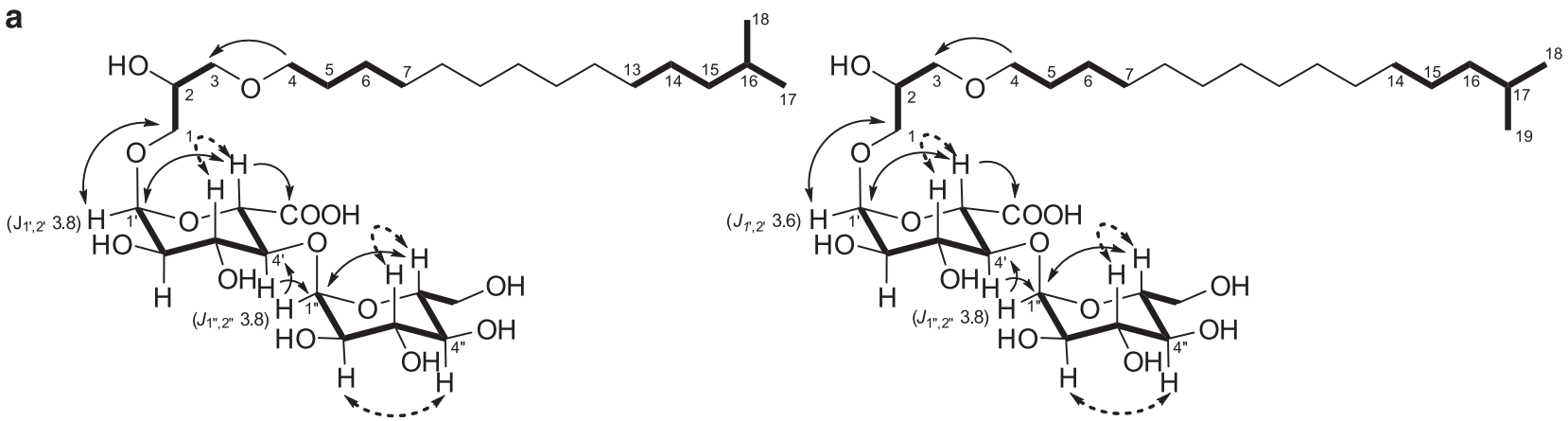

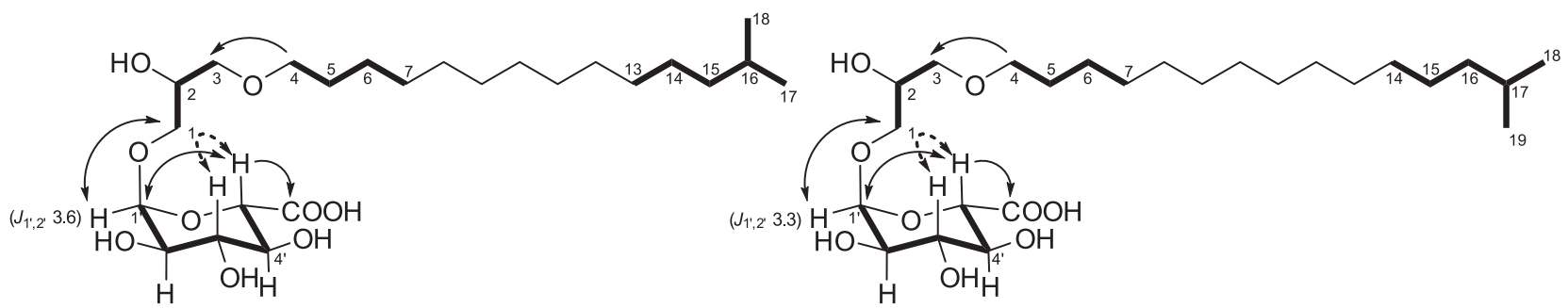

- ${ }^{1} \mathrm{H}-{ }^{1} \mathrm{H}$ COSY, 1D TOCSY

$\sim{ }^{1} \mathrm{H}-{ }^{13} \mathrm{C}$ HMBC

- ROE

b

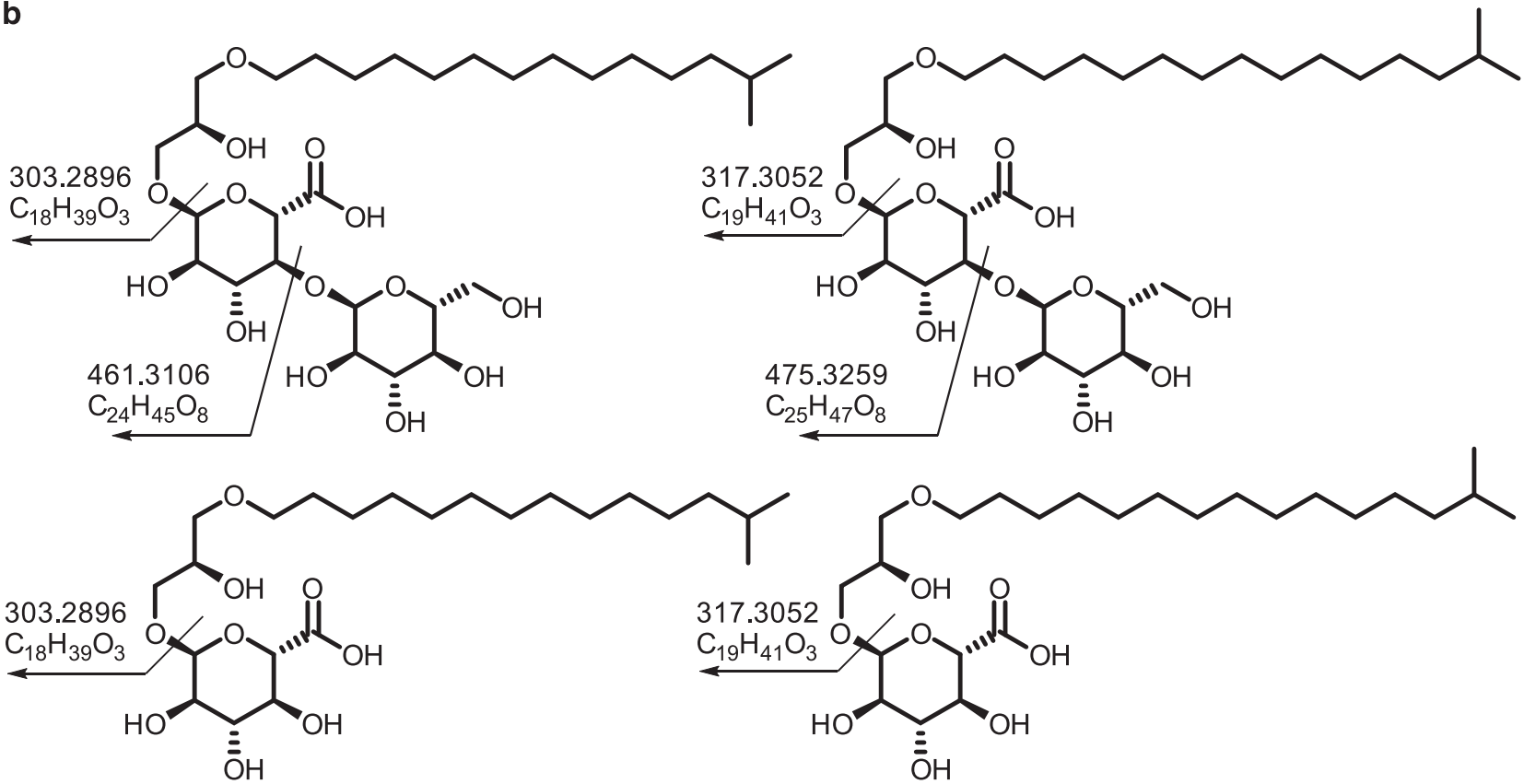

Figure 2 (a) COSY, HMBC and NOE analyses of the kribellosides. (b) ESI/MS fragment analysis of the kribellosides.

glucuronic acid. Furthermore, long-range connectivities were observed from $\mathrm{Hl}^{\prime}$ of the anomer proton of glucuronic acid to glyceryl oxymethylene of $\mathrm{H} 1$ and another glyceryl oxymethylene of $\mathrm{H} 3$ to H4 of the 13-methyl-1-tetradecanol moiety. Taken together, these results determined the planer structure of 1 . The length of the branched alkyl long chain was also established by the ESI/MS in source fragment $\left(m / z 303.2896\left(\mathrm{C}_{18} \mathrm{H}_{39} \mathrm{O}_{3}\right)\right)$ as shown in Figure $2 \mathrm{a}$.

The structures of compounds 2-4 were determined in the same manner and compared with the data for compound 1 . Comparisons of the molecular formula and the ${ }^{1} \mathrm{H}$ NMR spectra for $\mathbf{1}$ and $\mathbf{2}$ described above suggested a lack of glucose moiety in compound $\mathbf{1}$. Compound 2 was found to possess 1 carbonyl, 1 anomer, 5 oxymethines, $1 \mathrm{sp}^{3}$ methine, 3 oxygenated methylenes, 11 methylenes and 2 methyl carbons from the ${ }^{13} \mathrm{C}$ NMR and DEPT135 spectra. Furthermore, 1D and 2D spectral analyses revealed three parts, namely the glyceryl, 13-methyl-1-tetradecanol and glucuronic acid, that were the same as in compound $\mathbf{1}$. The difference between compounds $\mathbf{1}$ and $\mathbf{2}$ was the higher field shifts from $\mathrm{H}_{2}$ ' to $\mathrm{H}^{\prime}$ ' of glucuronic acid, as observed in the ${ }^{1} \mathrm{H}$ NMR spectrum. The same in source fragments of ESI/MS spectra for compounds $\mathbf{1}$ and $\mathbf{2}$ also supported this structure 


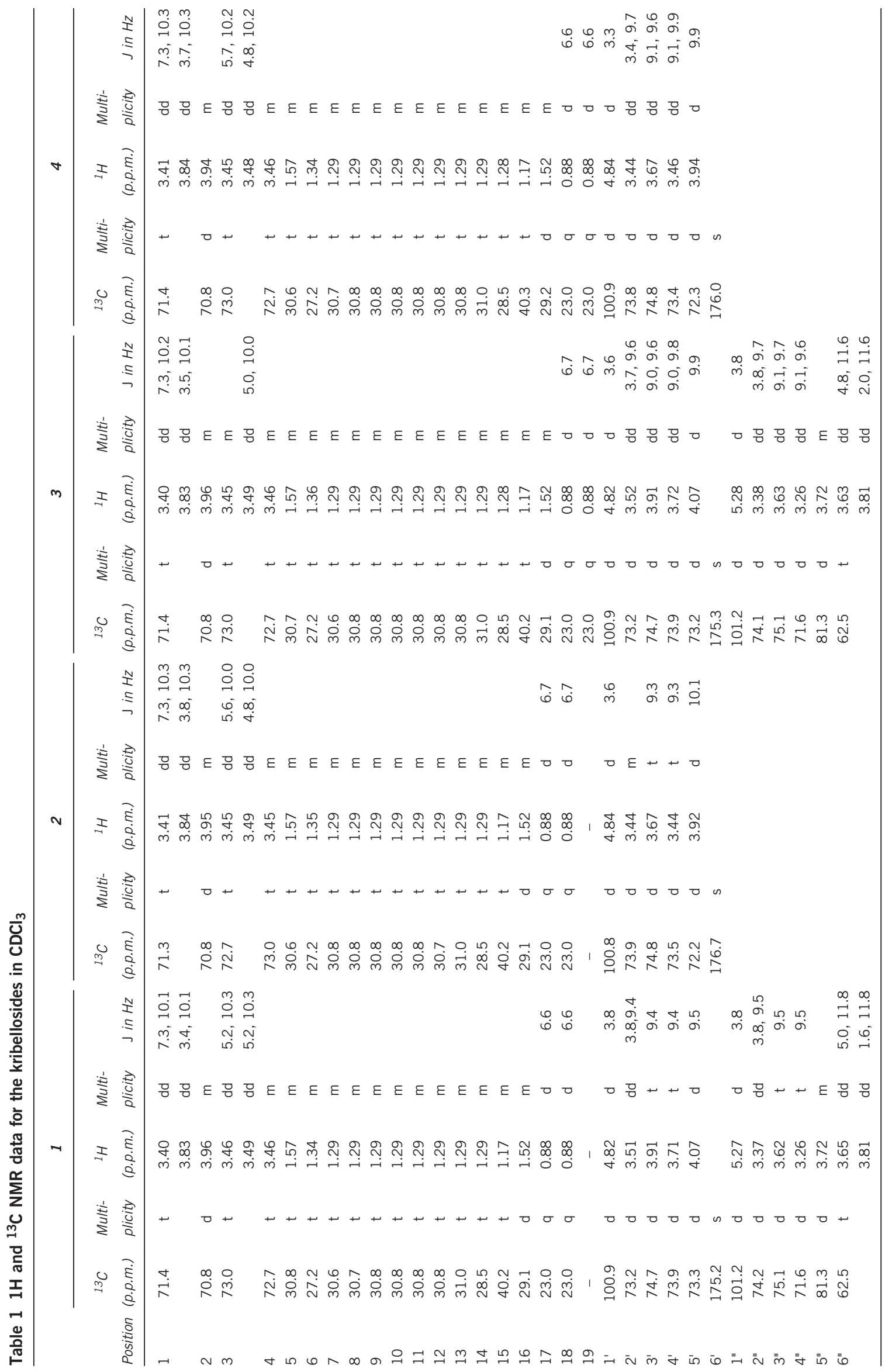



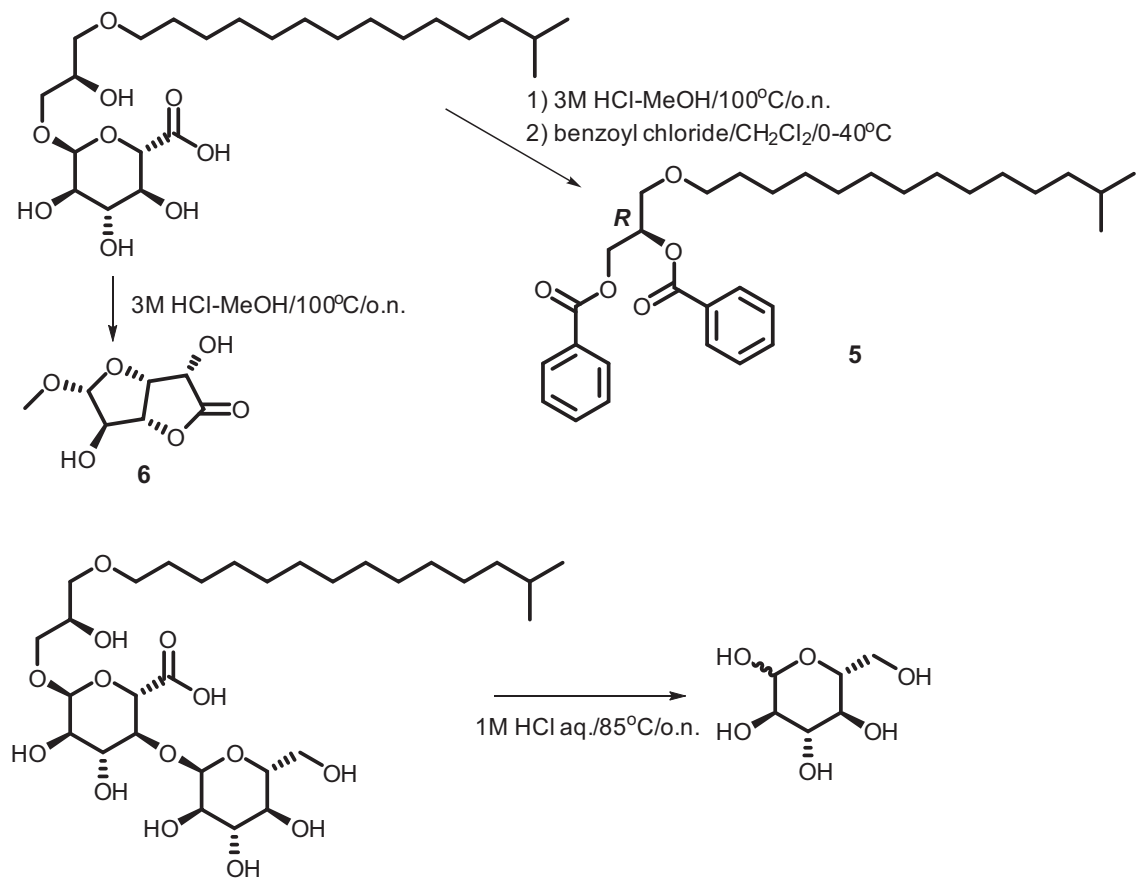

Figure 3 Degradation study of kribelloside A (1).

(Figure 2a). Thus, the structure of 2 was determined as shown in Figure 2. The structures of compounds 3 and 4 were similar to those of 1 and $\mathbf{2}$ with the exception of one methylene. The 2D analyses of compounds 3 and 4 revealed that they possessed 14-methyl1-pentadecanol instead of the 13-methyl-1-tetradecanol moiety of compounds 1 and 2 . This finding was supported by MS/ MS analysis. The structures of $\mathbf{3}$ and $\mathbf{4}$ were determined as shown in Figure $2 b$.

\section{Stereochemistry of the kribellosides}

The absolute chemistry of the $\mathrm{C} 2$ of glyceryl ether and the two sugar moieties of the kribellosides was determined by chemical degradations and their derivatives, as shown in Figure 3. Methanolysis of compound 2 indicated an aglycon and sugar moiety. The reaction mixture was partitioned by a solvent system of n-hexane- $\mathrm{MeOH}$ and the n-hexane layer containing aglycon was derivatized to dibenzoate $\mathbf{5}$. Since the CD spectrum of compound $\mathbf{5}$ indicated a negative cotton effect, the C2 was determined to be $R$ by the dibenzoate chirality method. ${ }^{14}$ The sugar moiety 6 described above was purified from the $\mathrm{MeOH}$ layer and identified as methyl- $\beta$-D-glucofuranuronic acid $\gamma$-lactone by comparing its NMR and CD spectra for the methanolysis product of D-glucuronic acid. Finally, the absolute chemistry of the glucose moiety in $\mathbf{1}$ was established to be $\mathrm{D}$ by the mutarotase-glucose oxidase method. ${ }^{15}$ Taking all of these results into account, the absolute chemistry of compounds $\mathbf{1}$ and $\mathbf{2}$ are shown in Figure 1. Compounds 3 and $\mathbf{4}$ showed the same stereochemistry, as indicated by the physicochemical properties and the NMR data.

Kribellosides are novel compounds that belong to the ether lipids. Ether lipids are known to be ubiquitous in the cell membranes of mammals, ${ }^{16}$ marine organisms ${ }^{17}$ and archaea. ${ }^{18}$ These ether lipids, however, are 1-O-alkyl lipids, whereas the 3-O-alkyl lipids in kribellosides are rare. Therefore, the 1-D-glucuronosyl-sn-glycerol 3-alkyl ether is a unique structure among the ether lipids.
Table 2 Inhibitory activities of the kribellosides towards the RNA 5 '-triphosphatase activities of Cet1p and hCap1

\begin{tabular}{lrrr} 
& \multicolumn{2}{c}{ IC50 ( $\mu \mathrm{M})$} \\
\cline { 2 - 3 } Compound & Cet1p & hCap1 & S/a \\
\hline Kribelloside A & 6.8 & 26.1 & 3.8 \\
Kribelloside B & 6.3 & 17.4 & 2.8 \\
Kribelloside C & 3.6 & 16.1 & 4.4 \\
Kribelloside D & 4.5 & 9.3 & 2.1 \\
Suramin & 0.7 & 5.4 & 7.9 \\
\hline
\end{tabular}

Abbreviation: SI, selectivity index.

${ }^{a}$ The $\mathrm{SI}$ as determined by the ratio of the $\mathrm{IC}_{50}$ values between hCapl and Cetlp.

\section{Biological activities of the kribellosides}

Cet1p inhibitory activity. We examined the inhibitory activity of kribellosides towards $S$. cerevisiae Cet1p using an in vitro enzyme assay. Since, suramin has been reported to inhibit Cetlp activity, and under our assay conditions it exhibited an $\mathrm{IC}_{50}$ value similar to that previously reported (Table 2), confirming that our assay conditions with $\left[\gamma_{-}{ }^{32} \mathrm{P}\right]$ triphosphate-ended $\operatorname{poly}(\mathrm{A})$ were appropriate for evaluating the inhibitory effect of compounds on triphosphatase activity. Upon treatment with kribelloside A, the hydrolysis of the $\gamma$ phosphate of triphosphate-ended RNA by Cetlp was inhibited in a dosedependent manner, with an $\mathrm{IC}_{50}$ of $6.8 \mu \mathrm{M}$ (Figure 4 and Table 2); whereas, kribellosides B, C and D inhibited Pi release from the RNA with $\mathrm{IC}_{50}$ values of $6.3,3.6$ and $4.5 \mu \mathrm{M}$, respectively. Furthermore, we evaluated the inhibitory potency of the compounds towards the RNA triphosphatase activity of human mRNA capping enzyme, hCap. Kribellosides A, B, C and D exhibited IC $_{50}$ values of 26.1, 17.4, 16.1 and $9.3 \mu \mathrm{M}$, yielding selectivity indexes of 3.8, 2.8, 4.4 and 2.1, respectively (Table 2 ). These results indicated that kribellosides are novel inhibitors of S. cerevisiae RNA 5'-triphosphatase. Glycosyl- 

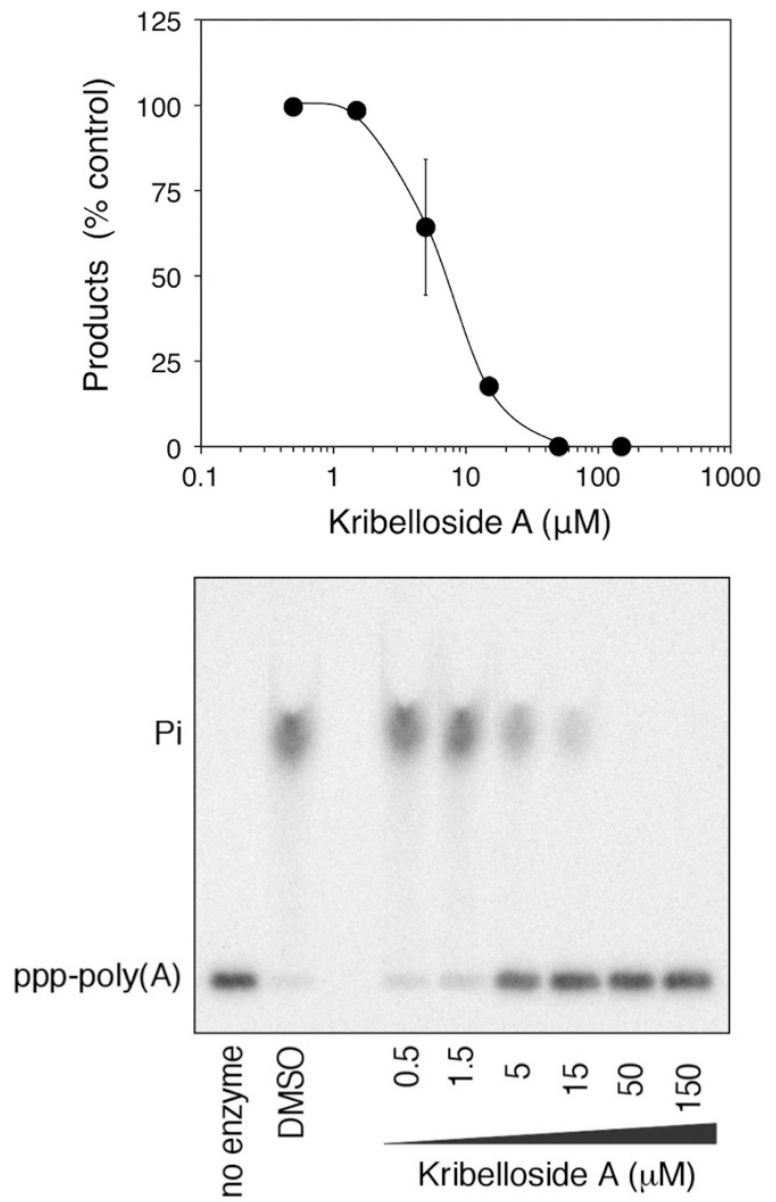

Figure 4 Inhibition of the RNA 5'-triphosphatase activity of Cet1p by kribelloside A. Triphosphatase activity by Cet1(201-549)p. The reaction was performed as described in the Materials and Methods using ${ }^{32} \mathrm{P}$ triphosphate-ended poly $(A)$. The reaction products were analyzed by $P E I$ cellulose TLC (upper panel) and quantified by phosphorimaging (lower panel). The relative amount of the released [ $\left.{ }^{32} \mathrm{P}\right] \mathrm{Pi}$ is shown as a percentage of that of the untreated control (DMSO). Results are shown as the means \pm s.d. from three independent experiments. DMSO, dimethyl sulfoxide; PEI, polyethyleneimine.

glycerol-alkyl ether has known biological activities, such as lipid hapten activity, ${ }^{19}$ antimicrobial activity ${ }^{20}$ and the inhibition of cancer metastasis. ${ }^{21}$ The 1-D-glucuronosyl-sn-glycerol 3-alkyl ether of kribellosides might be advantageous in its selectivity for the yeast enzyme (Table 2).

Antimicrobial activity. We evaluated the antimicrobial activity of kribellosides against $S$. cerevisiae. The anti-yeast activities of kribellosides are shown in Table 3. Kribellosides exhibited weak antiyeast activities against $S$. cerevisiae but no antibacterial activity against Gram-positive and Gram-negative bacteria (data not shown).

\section{MATERIALS AND METHODS}

\section{General experimental procedures}

The optical rotations of the isolated kribellosides were measured using a P-1030 polarimeter (JASCO, Tokyo, Japan). UV spectra were recorded using a U-2800 spectrophotometer (Hitachi High Technologies, Tokyo, Japan) and an FT/IR-4100 Fourier transform infrared spectrometer (JASCO) was employed. The ${ }^{1} \mathrm{H}$ and ${ }^{13} \mathrm{C}$ NMR spectra were measured using a JNM-ECA600 spectrometer (JEOL, Tokyo, Japan) at $25^{\circ} \mathrm{C}$ using tetramethylsilane as an internal
Table 3 Antimicrobial activities of the kribellosides

\begin{tabular}{lcccc}
\hline & \multicolumn{5}{c}{ MIC $\left(\mu g \mathrm{ml}^{-1}\right)$} \\
\cline { 2 - 5 } Test organisms & A & $B$ & $C$ & $D$ \\
\hline S. cerevisiae W303a & 100 & 50 & 100 & 12.5 \\
S. cerevisiae W303 $\alpha$ & 100 & 50 & 100 & 25 \\
S. cerevisiae SL101 & 50 & 50 & 100 & 12.5 \\
S. cerevisiae HC101 & 50 & 25 & 50 & 12.5 \\
S. cervisiae BY25929 & 25 & 12.5 & 12.5 & 3.12 \\
\hline
\end{tabular}

reference. The mass spectra were recorded using an LTQ Orbitrap XL mass spectrometer (Thermo Fisher Scientific, San Jose, CA, USA). HPLC was detected using an Evaporative Light Scattering Detector (Alltech Associates, Inc., Deerfield, IL, USA).

Taxonomic studies of the producing strain MI481-42F6

Morphological properties were observed following incubation at $30^{\circ} \mathrm{C}$ for 21 days on yeast extract-malt extract agar (ISP medium No. 2), oatmeal agar (ISP medium No. 3), inorganic salts-starch agar (ISP medium No. 4), glycerolasparagine agar (ISP medium No. 5) and tyrosine agar (ISP medium No. 7). Detailed observation of mycelial morphology was performed using a scanning electron microscope S-570 (Hitachi High-Technologies) after strain MI481$42 \mathrm{~F} 6$ had been incubated on ISP medium No. 3 at $30^{\circ} \mathrm{C}$ for 14 days. The type of diaminopimelic acid isomers in the whole-cell hydrolysates was determined by the method of Staneck and Roberts. ${ }^{22}$ Total DNA of strain MI481-42F6 was prepared using a Genomic DNA Extraction Kit Mini (RBC Bioscience Co., New Taipei, Taiwan) according to the manufacturer's instructions. 16S rRNA (positions 31-1524, Escherichia coli numbering system) ${ }^{23}$ was amplified by PCR and sequenced. A search for the most closely related sequences was performed using the BLAST algorithm in at the DNA Data Bank of Japan.

\section{Fermentation of kribellosides}

A slant culture of strain MI481-42F6 was inoculated into a 500-ml baffled Erlenmeyer flask containing $110 \mathrm{ml}$ of a seed medium consisting of $2 \%(\mathrm{w} / \mathrm{v})$ galactose, 2\% (w/v) dextrin, 1\%(w/v) Bacto Soytone (Becton Dickinson, Franklin Lakes, NJ, USA), $0.5 \%$ (w/v) corn steep liquor (Kogo starch, Chiba, Japan), $1 \%(\mathrm{w} / \mathrm{v})$ glycerol, $0.2 \%(\mathrm{w} / \mathrm{v})\left(\mathrm{NH}_{4}\right)_{2} \mathrm{SO}_{4}$ and $0.2 \%(\mathrm{w} / \mathrm{v}) \mathrm{CaCO}_{3}$ in deionized water ( $\mathrm{pH} 7.4$ before sterilization). The seed culture was incubated on a rotary shaker $(200$ r.p.m. $)$ at $30^{\circ} \mathrm{C}$ for four days. The seed culture $(2.5 \mathrm{ml})$ of the strain was then transferred into a 500-ml baffled Erlenmeyer flask containing $110 \mathrm{ml}$ of a producing medium consisting of $2.0 \%$ glycerin, $2.0 \%$ dextrin, $1.0 \%$ Bacto Soytone (Becton Dickinson), $0.3 \%$ yeast extract (Nihon Pharmaceutical Co., Ltd, Tokyo, Japan), $0.2 \%\left(\mathrm{NH}_{4}\right)_{2} \mathrm{SO}_{4}$ and $0.2 \% \mathrm{CaCO}_{3}$ in deionized water ( $\mathrm{pH} 7.4$ before sterilization). The fermentation was carried out on a rotary shaker $\left(180\right.$ r.p.m.) at $27^{\circ} \mathrm{C}$ for 7 days.

\section{Purification of kribellosides}

The fermentation broth (4l) was separated into the mycelial cake and supernatant by centrifugation. The mycelial cake was extracted with $\mathrm{MeOH}$ (11). The $\mathrm{MeOH}$ solution was removed in vacuo to yield a brown oil. The brown oil, including an active substance, was extracted with $\mathrm{BuOH}$ and concentrated in vacuo to give $1.4 \mathrm{~g}$ of a brown oil. The $1.4 \mathrm{~g}$ of brown oil was extracted with a mixture of $\mathrm{CHCl}_{3}-\mathrm{MeOH}$-water $(5: 4: 6,11)$. The upper layer was collected and concentrated in vacuo to dryness yielding a brown material (764 mg). The brown material was subjected to chromatography on a low-pressure reversed-phase $(20 \times 250 \mathrm{~mm}$, ODS-7515-12 A, Senshu Scientific co., Tokyo, Japan) column developed with $\mathrm{MeOH}$ :ammonium carbonate $(5 \mathrm{~mm})$ at a ratio of 0:100, 60:40, 80:20 and 100:0. The active fractions were eluted with a ratio of 80:20 and 0:100, and concentrated in vacuo to give a pale brown oil $(427 \mathrm{mg})$. The active material was subjected to further chromatography on reversed-phase HPLC (Capcell Pak UG C18, $30 \times 250 \mathrm{~mm}$, Shiseido Co., Ltd., Japan) developed with acetonitrile:ammonium carbonate (5 mM) at 
5:95 (0 min) to 50:50 (60 $\mathrm{min})$ and $50: 50(80 \mathrm{~min})$ at a flow rate of $10 \mathrm{ml} \mathrm{min}{ }^{-1}$. The active fractions were collected and concentrated in vacuo to yield $79 \mathrm{mg}$ of pure kribelloside A (rt: 61-63 min), $83 \mathrm{mg}$ of kribelloside B (rt: 63-64 min), $26 \mathrm{mg}$ of kribelloside C (rt: 65-66 min) and $13 \mathrm{mg}$ of kribelloside D (rt: 67-68 min), respectively, as a colorless powder.

\section{Analytical procedure}

The kribellosides in the fermentation broth and the various purification steps were monitored by reversed-phase HPLC and silica gel TLC. HPLC was performed on a reversed-phase HPLC column (Capcell Pak UG C18, $4.6 \times 150 \mathrm{~mm}$, Shiseido, Japan; mobile phase, acetonitrile:ammonium carbonate $(5 \mathrm{~mm})$ at a ratio of 45:55; flow rate, $1 \mathrm{ml} \mathrm{min}^{-1}$; column temperature, $25^{\circ} \mathrm{C}$; detection, evaporative light scattering detector). Kribellosides A, B, C and $\mathrm{D}$ were eluted at $6.5,8.1,10.3$ and $12.8 \mathrm{~min}$, respectively. A spot of each antibiotic on TLC plates was detected by TLC (Kieselgel 60 F254, Art. No. 5715, Merck) using a solution of molybdophosphoric acid and sulfuric acid in water. The resulting Rf values for kribellosides A, B, C and D were $0.26,0.36,0.29$ and 0.40 , respectively, using the solvent system of $\mathrm{CHCl}_{3}: \mathrm{MeOH}: \mathrm{H}_{2} \mathrm{O}$ at a ratio of 10:5:1.

\section{(R)-3-((13-methyltetradecyl)oxy)propane-1,2-diyl dibenzoate (5)}

Compound $2(27.0 \mathrm{mg})$ was dissolved in $3 \mathrm{M}$ of hydrogen chloride-methanol and stirred at $100{ }^{\circ} \mathrm{C}$ for $14 \mathrm{~h}$. The solution was added to $6 \mathrm{ml}$ of $n$-hexane and partitioned. The $n$-hexane layer was dried to yield $10.3 \mathrm{mg}$ of crude aglycon. The methanol layer was dried and re-dissolved in $100 \mathrm{ml}$ of methanol and $1.8 \mathrm{ml}$ of acetonitrile and then centrifuged at 2500 r.p.m. for $5 \mathrm{~min}$. The supernatant was concentrated and subjected to hydrophilic interaction liquid chromatography (PC HILIC, $20 \times 250 \mathrm{~mm}$, Shiseido, $97 \%$ acetonitrile). The eluent of fraction No. 18 containing aglycon was combined with the residue of the $n$-hexane layer, then evaporated in vacuo to yield $13.0 \mathrm{mg}$ of crude aglycon. The residue was dissolved in $1.5 \mathrm{ml}$ of dichloromethane and benzoyl chloride (14.3 mg, Tokyo Chemical Industry Co. Ltd.) and potassium carbonate $(9.0 \mathrm{mg})$ were added and stirred at $0{ }^{\circ} \mathrm{C}$ to $40^{\circ} \mathrm{C}$ gently for $13 \mathrm{~h}$. The reaction mixture was filtered and subjected to preparative TLC (Kieselgel 60 F254, Art. No. 5715) developed with $n$-hexane:ethylacetate at a ratio of 2:1 to give $1.5 \mathrm{mg}$ of compound $\mathbf{5}$ as a colorless syrup.

(R)-3-((13-methyltetradecyl)oxy)propane-1,2-diyl dibenzoate (5): colorless syrup; ${ }^{1} \mathrm{H}$ NMR $\left(\mathrm{CDCl}_{3}, 600 \mathrm{MHz}\right) \delta 8.05(2 \mathrm{H}, \mathrm{m}, \mathrm{Ph}), 8.02(2 \mathrm{H}, \mathrm{m}, \mathrm{Ph}), 7.56$ $(1 \mathrm{H}, \mathrm{m}, \mathrm{Ph}), 7.55(1 \mathrm{H}, \mathrm{m}, \mathrm{Ph}), 7.43(2 \mathrm{H}, \mathrm{m}, \mathrm{Ph}), 7.42(2 \mathrm{H}, \mathrm{m}, \mathrm{Ph}), 5.59$ $(1 \mathrm{H}, \mathrm{m}, \mathrm{H} 2), 4.68(1 \mathrm{H}, \mathrm{dd}, \mathrm{J}=3.7,11.9 \mathrm{~Hz}, \mathrm{H1a}), 4.61(1 \mathrm{H}, \mathrm{dd}, \mathrm{J}=6.5$, $11.9 \mathrm{~Hz}, \mathrm{Hlb}), 3.79(1 \mathrm{H}, \mathrm{dd}, \mathrm{J}=5.3,10.5 \mathrm{~Hz}, \mathrm{H} 3 \mathrm{a}), 3.76(1 \mathrm{H}, \mathrm{dd}, \mathrm{J}=5.2$, $10.5 \mathrm{~Hz}, \mathrm{H} 3 \mathrm{~b}), 3.50$ (1H, m, H1'), $1.24\left(1 \mathrm{H}, \mathrm{m}, \mathrm{H} 2^{\prime}\right), 1.31$ (1H, m, H3'), 1.24 $\left(16 \mathrm{H}, \mathrm{m}, \mathrm{H} 4^{\prime}-11^{\prime}\right), 1.15\left(2 \mathrm{H}, \mathrm{m}, \mathrm{H} 12^{\prime}\right), 1.51\left(1 \mathrm{H}, \mathrm{m}, \mathrm{H} 13^{\prime}\right), 0.86(6 \mathrm{H}, \mathrm{d}$, $\mathrm{J}=6.6 \mathrm{~Hz}, \mathrm{H} 14,15),{ }^{13} \mathrm{C} \mathrm{NMR}\left(\mathrm{CDCl}_{3}, 150 \mathrm{MHz}\right) \delta 166.3$ (benzyl CO), 165.9 (benzyl CO), $133.14(\mathrm{Ph}), 133.09(\mathrm{Ph}), 130.0(\mathrm{Ph}), 129.9(\mathrm{Ph}), 129.8(\mathrm{Ph})$, $129.8(\mathrm{Ph}), 129.7(\mathrm{Ph}), 129.7(\mathrm{Ph}), 128.4(\mathrm{Ph}), 128.4(\mathrm{Ph}), 128.4(\mathrm{Ph}), 128.4$ (Ph), 71.9 (C-4), 71.1 (C-2), 69.0 (C-3), 63.7 (C-1), 39.1 (C-15), 30.0, 29.74, 29.69, 29.69, 29.61, 29.61, 29.5, 26.1 (C-7-14), 29.62 (C-5), 28.0 (C-16), 27.4 (C-6), 22.7 (C-17), 22.7 (C-18); HRESI/MS [M+Na ${ }^{+} \mathrm{m} / z 533.3227$ (calcd for $\left.\mathrm{C}_{32} \mathrm{H}_{46} \mathrm{O}_{5} \mathrm{Na}, 533.3237\right)$.

\section{Methyl $\beta$-D-glucofuranosiduronic acid $\gamma$-lactone from 2 and D-glucuronic acid (6 and $6^{\prime}$ )}

The fraction No. 26 to 27 obtained by hydrophilic interaction liquid chromatography described above was evaporated in vacuo to give $2.0 \mathrm{mg}$ of methyl- $\beta$-D-glucofuranosiduronic acid $\gamma$-lactone (6) as a colorless syrup: ${ }^{1} \mathrm{H}$ NMR $\left(600 \mathrm{MHz}, \mathrm{CD}_{3} \mathrm{OD}\right) \delta 4.91(1 \mathrm{H}, \mathrm{s}, \mathrm{H} 1), 4.91(1 \mathrm{H}, \mathrm{dd}, J=4.6$, $6.5 \mathrm{~Hz}, \mathrm{H} 4), 4.80(1 \mathrm{H}, \mathrm{d}, J=4.6 \mathrm{~Hz}, \mathrm{H} 3), 4.49(1 \mathrm{H}, \mathrm{d}, J=6.4 \mathrm{~Hz}, \mathrm{H} 5), 4.18$ $(1 \mathrm{H}, \mathrm{s}, \mathrm{H} 2), 3.33\left(3 \mathrm{H}, \mathrm{s}, \mathrm{OCH}_{3}\right) .{ }^{13} \mathrm{C}$ NMR $\left(\mathrm{CD}_{3} \mathrm{OD}\right) \delta 177.1(\mathrm{C}=\mathrm{O}), 111.6$ (C-1), 84.7 (C-3), 79.5 (C-4), 78.6 (C-2), 70.6 (C-5), $55.7\left(\mathrm{OCH}_{3}\right)$; HRESI/MS $[\mathrm{M}+\mathrm{Na}]^{+} \mathrm{m} / \mathrm{z} 213.0372$ (calcd for $\mathrm{C}_{7} \mathrm{H}_{10} \mathrm{O}_{6} \mathrm{Na}, 213.0370$ ).

As an authentic sample of compound $\mathbf{6}, 38.0 \mathrm{mg}$ of D-glucuronic acid (Tokyo Chemical Industry Co. Ltd.) was dissolved in $3 \mathrm{~m}$ of hydrogen chloride-methanol and stirred at room temperature for $1 \mathrm{~h}$. The reaction mixture was concentrated and the residue was applied for hydrophilic interaction liquid chromatography using the same method described above.
Fractions No. 26 and 27 were collected and concentrated to dryness to give $16 \mathrm{mg}$ of a colorless syrup of methyl- $\beta$-D-glucofuranosiduronic acid $\gamma$-lactone $\left(6^{\prime}\right):{ }^{1} \mathrm{H}$ NMR $\left(600 \mathrm{MHz}, \mathrm{CD}_{3} \mathrm{OD}\right) \delta 4.92(1 \mathrm{H}, \mathrm{s}, \mathrm{H} 1), 4.91(1 \mathrm{H}, \mathrm{dd}, J=4.6$, $6.4 \mathrm{~Hz}, \mathrm{H} 4), 4.81(1 \mathrm{H}, \mathrm{d}, J=4.6 \mathrm{~Hz}, \mathrm{H} 3), 4.50(1 \mathrm{H}, \mathrm{d}, J=6.4 \mathrm{~Hz}, \mathrm{H} 5), 4.18$ $(1 \mathrm{H}, \mathrm{s}, \mathrm{H} 2), 3.33(3 \mathrm{H}, \mathrm{s}, \mathrm{OCH} 3) .{ }^{13} \mathrm{C} \mathrm{NMR}\left(\mathrm{CD}_{3} \mathrm{OD}\right) \delta 177.1(\mathrm{C}=\mathrm{O}), 111.6$ (C-1), 84.7 (C-3), 79.4 (C-4), 78.5 (C-2), 70.5 (C-5), $55.7\left(\mathrm{OCH}_{3}\right)$; HRESI/MS $[\mathrm{M}+\mathrm{Na}]^{+} \mathrm{m} / \mathrm{z} 213.0373$ (calcd for $\mathrm{C}_{7} \mathrm{H}_{10} \mathrm{O}_{6} \mathrm{Na}, 213.0370$ ).

\section{Mutarotase-glucose oxidase method}

Compound $1(2.3 \mathrm{mg})$ was dissolved in $1 \mathrm{M} \mathrm{HCl}(1 \mathrm{ml})$ and the solution was heated at $85^{\circ} \mathrm{C}$ for $12 \mathrm{~h}$. The reaction mixture was dried to remove the acid. The residue was dissolved in water and washed with ethylacetate. The aqueous solution was evaporated in vacuo. The residue was dissolved in water $(200 \mu \mathrm{l}$, $1 \times)$, and its concentration was halved $(2 \times)$ for the sample solution. Standard D-glucose solutions (100, 500, 1000 and $2000 \mu \mathrm{g} \mathrm{ml}^{-1}$ ) and negative controls of the L-glucose solution $\left(1000 \mu \mathrm{g} \mathrm{m}^{-1}\right)$ and D-glucuronic acid $\left(1000 \mu \mathrm{g} \mathrm{ml}^{-1}\right)$ were prepared. The detection of D-glucose was performed using the mutarotase-glucose oxidase method. ${ }^{18}$ The sample, standard, negative control and blank solutions (each $20 \mu \mathrm{l}$ ) were added to $3 \mathrm{ml}$ of glucose CII kit enzyme solution at $37^{\circ} \mathrm{C}$ for $5 \mathrm{~min}$. Then, the reaction mixtures were measured at an absorption of $505 \mathrm{~nm}$. For the standard D-glucose solutions $(0,500,1000$ and $2000 \mu \mathrm{g} \mathrm{ml}^{-1}$ ), OD values of $0,0.097,0.217$ and 0.462 were recorded, and for the $1 \times$ and $2 \times$ sample solutions, OD values of 0.374 and 0.188 were recorded, respectively. No absorption was detected for the $1000 \mu \mathrm{g} \mathrm{ml}^{-1}$ solution of L-glucose and D-glucuronic acid.

\section{Screening system for RNA 5'-triphosphatase inhibitor}

Nucleoside triphosphatase assay. The S. cerevisiae Cet1(201-549)p was expressed in Escherichia coli as an N-terminal hexahistidine (His)-tagged protein and purified by nickel-agarose and ion exchange chromatography. An nucleoside triphosphatase assay with Cet1(201-549)p was performed on a 96-well microplate for initial screening of metabolites from actinomycetes. Aliquots of $40 \mu \mathrm{l}$ of a reaction mixture containing $50 \mathrm{~mm}$ Tris- $\mathrm{HCl}(\mathrm{pH} 7.5$ ), $2 \mathrm{mM} \mathrm{MnCl}_{2}$ and $8 \mathrm{nM} \mathrm{Cet1(201-549)p} \mathrm{were} \mathrm{dispensed} \mathrm{into} \mathrm{each} \mathrm{well,} \mathrm{and}$ then $5 \mu \mathrm{l}$ of test sample was added to the mixture. After preincubation for $5 \mathrm{~min}$, the reaction was started by adding $5 \mu \mathrm{l}$ of $400 \mu \mathrm{M}$ ATP. After incubation at $30^{\circ} \mathrm{C}$ for $1 \mathrm{~h}, 75 \mu \mathrm{l}$ of MicroMolar Phosphate Assay Reagent (ProFoldin, Hudson, MA, USA) was added, and the mixtures were incubated for $5 \mathrm{~min}$. The absorbance at $620 \mathrm{~nm}$ was read using a plate reader (ARVOSX 1420 Multilabel counter; PerkinElmer, Waltham, MA, USA).

\section{RNA 5'-triphosphatase assays for Cetlp and hCap}

The hCap1 was expressed in E. coli as an N-terminal His-tagged protein and purified by nickel-agarose and ion exchange chromatography. RNA 5'-triphosphatase assays for Cetlp and hCap were performed as described previously with a minor modification. ${ }^{24,25}$ The reaction mixtures for Cetlp containing $50 \mathrm{~mm}$ Tris- $\mathrm{HCl}$ ( $\mathrm{pH} 7.9), 0.5 \mathrm{~mm} \mathrm{MgCl}_{2}, 40 \mu \mathrm{g}$ of bovine serum albumin and $4 \mathrm{~nm}$ Cet1(201-549)p, and for hCap1 containing $50 \mathrm{~mm}$ Tris-HCl (pH 7.9), $2 \mathrm{~mm}$ DTT, $40 \mu \mathrm{g}$ of bovine serum albumin and $0.23 \mathrm{~nm}$ hCap in a final volume of $10 \mu \mathrm{l}$ were preincubated with various compounds for $10 \mathrm{~min}$. The reaction was then started by adding $50 \mathrm{~nm}\left[\gamma^{32} \mathrm{P}\right]$-radiolabeled triphosphateended poly(A). After incubation at $30^{\circ} \mathrm{C}$ for $10 \mathrm{~min}$, the reaction products were analyzed by polyethyleneimine cellulose TLC with $0.5 \mathrm{M}$ potassium phosphate buffer ( $\mathrm{pH}$ 3.4). The TLC plate was exposed to an imaging plate and visualized using the phosphorimager Typhoon Variable Model Imager (GE Healthcare, Piscataway, NJ, USA), and the $50 \%$ inhibition concentration $\left(\mathrm{IC}_{50}\right)$ was calculated by four-parameter logistic curve fitting.

\section{Antimicrobial activity}

MICs were determined by the standard agar dilution method recommended by the Clinical Laboratory Standards Institute (CLSI) guidelines. ${ }^{26}$ Bacteria were incubated on Mueller-Hinton agar (Becton Dickinson) at $37^{\circ} \mathrm{C}$ for $18 \mathrm{~h}$, whereas yeast were incubated for $42 \mathrm{~h}$. 


\section{CONFLICT OF INTEREST}

The authors declare no conflict of interest.

\section{ACKNOWLEDGEMENTS}

This study was supported by the Japan Society for the Promotion of Science (26450107). The authors would like to thank Y. Kubota, Y. Takahashi, R. Arisaka, R. Nagasaka and T. Suzuki for providing technical assistance.

1 Jove, R. \& Manley, J. L. Transcription initiation by RNA polymerase II is inhibited by S-adenosylhomocysteine. Proc. Natl Acad. Sci. USA 79, 5842-5846 (1982).

2 Rasmussen, E. B. \& Lis, J. T. In vivo transcriptional pausing and cap formation on three Drosophila heat shock genes. Proc. Natl Acad. Sci. USA 90, 7923-7927 (1993).

3 Chiu, Y. L. et al. Tat stimulates cotranscriptional capping of HIV mRNA. Mol. Cell 10, 585-597 (2002).

4 Tsukamoto, $\mathrm{T}$. et al. Isolation and characterization of the yeast mRNA capping enzyme beta subunit gene encoding RNA 5'-triphosphatase, which is essential for cell viability. Biochem. Biophys. Res. Commun. 239, 116-122 (1997).

5 Lima, C. D., Wang, L. K. \& Shuman, S. Structure and mechanism of yeast RNA triphosphatase: an essential component of the mRNA capping apparatus. Cell 99, 533-543 (1999).

$6 \mathrm{Gu}, \mathrm{M}$. \& Lima, C. D. Processing the message: structural insights into capping and decapping mRNA. Curr. Opin. Struct. Biol. 15, 99-106 (2005).

7 Benarroch, D., Smith, P. \& Shuman, S. Characterization of a trifunctional mimivirus mRNA capping enzyme and crystal structure of the RNA triphosphatase domain. Structure 16, 501-512 (2008).

8 Tsukamoto, T. et al. Cloning and characterization of two human cDNAs encoding the mRNA capping enzyme. Biochem. Biophys. Res. Commun. 243, 101-108 (1998).

9 Changela, A. et al. Structure and mechanism of the RNA triphosphatase component of mammalian mRNA capping enzyme. EMBO J. 20, 2575-2586 (2001).

10 Wen, Y., Yue, Z. \& Shatkin, A. J. Mammalian capping enzyme binds RNA and uses protein tyrosine phosphatase mechanism. Proc. Natl Acad. Sci. USA 95 12226-12231 (1998)
11 Carlsohn, M. R. et al. Kribbella aluminosa sp. nov., isolated from a medieval alum slate mine. Int. J. Syst. Evol. Microbiol. 57, 1943-1947 (2007)

12 Song, J. et al. Kribbella solani sp. nov. and Kribbella jejuensis sp. nov., isolated from potato tuber and soil in Jeju, Korea. Int. J. Syst. Evol. Microbiol. 54, 1345-1348 (2004).

13 Ho, C. K., Pei, Y. \& Shuman, S. Yeast and viral RNA 5' triphosphatases comprise a new nucleoside triphosphatase family. J. Biol. Chem. 273, 34151-34156 (1998).

14 Harada, N. et al. A CD method for determination of the absolute stereochemistry of acyclic glycols.2. Application of the $C D$ exciton chirality method to acyclic 1,2-dibenzoates systems. Enantiomer 1, 119-138 (1996).

15 Miwa, I., Okudo, J., Maeda, K. \& Okuda, G. Mutarotase effect on colorimetric determination of blood glucose with -D-glucose oxidase. Clin. Chim. Acta 37, 538 (1972).

16 Paltauf, F. Ether lipids in biomembranes. Chem. Phys. Lipids. 74, 101-139 (1994).

17 Bordier, C. G., Sellier, N., Foucault, A. P. \& Le Goffic, F. Purification and characterization of deep sea shark Centrophorus squamosus liver oil 1-0-alkylglycerol ether lipids. Lipids 31, 521-528 (1996).

18 Koga, Y. \& Morii, H. Recent advances in structural research on ether lipids from archaea including comparative and physiological aspects. Biosci. Biotechnol. Biochem. 69 2019-2034 (2005)

19 Coulon-Morelec, M. J., Faure, M. \& Marechal, J. Serological properties of glucuronic cid-containing lipid glycosides. Lipid haptens. Ann. Inst. Pasteur (Paris) 113, 37-57 (1967).

20 Subrahmanyam, C. \& Kulatheeswaran, R. Bioactive compounds from a new species of Sinularia soft coral. Indian J. Chem. Sect. B 38B, 1388-1390 (1999).

21 Vandier, C. et al. Method for preventing cancer metastasis with glycerolipids. WO 2011101408 A1 20110825 (2011).

22 Staneck, J. L. \& Roberts, G. D. Simplified approach to identification of aerobic actinomycetes by thin-layer chromatography. Appl. Microbiol. 28, 226-231 (1974).

23 Brosius, J., Palmer, M. L., Kennedy, P. J. \& Noller, H. F. Complete nucleotide sequence of a 16 S ribosomal RNA gene from Escherichia coli. Proc. Natl Acad. Sci. USA 75 4801-4805 (1978).

24 Itoh, N., Mizumoto, K. \& Kaziro, Y. Messenger RNA guanylyltransferase from Saccharomyces cerevisiae. I. Purification and subunit structure. J. Biol. Chem. 259, 13923-13929 (1984).

25 Yagi, Y., Mizumoto, K. \& Kaziro, Y. Association of an RNA 5'-triphosphatase activity with RNA guanylyltransferase partially purified from rat liver nuclei. EMBO J. 2 611-615 (1983).

26 Clinical and Laboratory Standards Institute. Reference method for broth dilution antifungal susceptibility testing of yeasts; Approved standard-third edition M27-A3, CLSI, Wayne, PA, USA, 2008. 